\title{
Front Matter: Volume 10978
}

, "Front Matter: Volume 10978," Proc. SPIE 10978, Advanced Photon Counting Techniques XIII, 1097801 (3 July 2019); doi: 10.1117/12.2536822

SPIE Event: SPIE Defense + Commercial Sensing, 2019, Baltimore, MD, United SPIE. States 


\title{
PROCEEDINGS OF SPIE
}

\section{Advanced Photon Counting Techniques XIII}

\author{
Mark A. Itzler \\ Joshua C. Bienfang \\ K. Alex McIntosh \\ Editors
}

17-18 April 2019

Baltimore, Maryland, United States

Sponsored and Published by

SPIE

Volume 10978 
The papers in this volume were part of the technical conference cited on the cover and title page. Papers were selected and subject to review by the editors and conference program committee. Some conference presentations may not be available for publication. Additional papers and presentation recordings may be available online in the SPIE Digital Library at SPIEDigitallibrary.org.

The papers reflect the work and thoughts of the authors and are published herein as submitted. The publisher is not responsible for the validity of the information or for any outcomes resulting from reliance thereon.

Please use the following format to cite material from these proceedings:

Author(s), "Title of Paper," in Advanced Photon Counting Techniques XIII, edited by Mark A. Itzler, Joshua C. Bienfang, K. Alex Mclntosh, Proceedings of SPIE Vol. 10978 (SPIE, Bellingham, WA, 2019) Seven-digit Article CID Number.

ISSN: 0277-786X

ISSN: 1996-756X (electronic)

ISBN: 9781510626218

ISBN: 9781510626225 (electronic)

Published by

SPIE

P.O. Box 10, Bellingham, Washington 98227-0010 USA

Telephone +1 3606763290 (Pacific Time) · Fax +1 3606471445

SPIE.org

Copyright @ 2019, Society of Photo-Optical Instrumentation Engineers.

Copying of material in this book for internal or personal use, or for the internal or personal use of specific clients, beyond the fair use provisions granted by the U.S. Copyright Law is authorized by SPIE subject to payment of copying fees. The Transactional Reporting Service base fee for this volume is $\$ 18.00$ per article (or portion thereof), which should be paid directly to the Copyright Clearance Center (CCC), 222 Rosewood Drive, Danvers, MA 01923. Payment may also be made electronically through CCC Online at copyright.com. Other copying for republication, resale, advertising or promotion, or any form of systematic or multiple reproduction of any material in this book is prohibited except with permission in writing from the publisher. The CCC fee code is $0277-$ $786 \times / 19 / \$ 18.00$.

Printed in the United States of America by Curran Associates, Inc., under license from SPIE.

Publication of record for individual papers is online in the SPIE Digital Library.

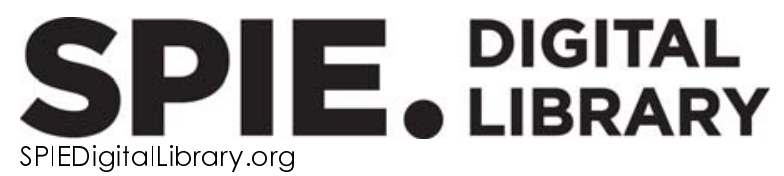

Paper Numbering: Proceedings of SPIE follow an e-First publication model. A unique citation identifier (CID) number is assigned to each article at the time of publication. Utilization of CIDs allows articles to be fully citable as soon as they are published online, and connects the same identifier to all online and print versions of the publication. SPIE uses a seven-digit CID article numbering system structured as follows:

- The first five digits correspond to the SPIE volume number.

- The last two digits indicate publication order within the volume using a Base 36 numbering system employing both numerals and letters. These two-number sets start with 00, 01, 02, 03, 04, 05, 06, 07, 08, 09, 0A, OB ... 0Z, followed by 10-1Z, 20-2Z, etc. The CID Number appears on each page of the manuscript. 


\section{Contents}

$\begin{array}{ll}\vee & \text { Authors } \\ \text { vii } & \text { Conference Committee }\end{array}$

SESSION $1 \quad$ SPD APPLICATIONS I: TOF IMAGING

1097803 Detection, identification, and tracking of objects hidden from view with neural networks (Invited Paper) [10978-2]

SESSION 2 SPD APPLICATIONS II: LADAR IMAGING

1097807 Outdoor single-photon counting panoramic 3D imaging (Invited Paper) [10978-6]

SESSION $3 \quad$ SPD APPLICATIONS III: SPACE DETECTION

1097808 Status of ELROI satellite license plate demonstration on the CubeSat NMTSat (Invited Paper) [10978-7]

1097809 Photon counting camera for the NASA deep space optical communication demonstration on the PSYCHE mission (Invited Paper) [10978-8]

10978 OA The SAPHIRA detector: a near-infrared photon counter for astronomy (Invited Paper) [10978-9]

10978 OB IceSat-2 ATLAS photon-counting receiver: initial on-orbit performance (Invited Paper)

[10978-10]

\section{SESSION 4 SPADS AND ELECTRONICS}

10978 0C Design and performance study of actively holding-off GHz-gated InGaAs/InP SPADs [10978-11]

10978 OD Fast fully integrated active quenching circuit for single photon counting up to 160 Mcounts/s (Rising Researcher Paper) [10978-12]

10978 OF Design of low noise avalanche photodiode single element detectors and linear arrays through CMOS process [10978-25] 
$10978 \mathrm{OH} \quad$ Modeling the missing part of CMOS silicon photomultiplier: the ultimate photon counting and timing sensor (Invited Paper) [10978-15]

10978 Ol High performance single photon counting and timing with single photon avalanche diodes (Invited Paper) [10978-16]

SESSION 6 NOVEL SPDS

10978 OM From single photon counting to high rate capability with fast timing MCP-PMTs for LIDAR [10978-20]

\section{SESSION $7 \quad$ SNSPDS}

10978 ON Towards single-photon spectroscopy in the mid-infrared using superconducting nanowire single-photon detectors (Invited Paper) [10978-21]

SESSION 8 SPADS II

$109780 Q \quad 256 \times 256$ dual-mode CMOS SPAD image sensor [10978-26] 


\section{Authors}

Numbers in the index correspond to the last two digits of the seven-digit citation identifier (CID) article numbering system used in Proceedings of SPIE. The first five digits reflect the volume number. Base 36 numbering is employed for the last two digits and indicates the order of articles within the volume. Numbers start with 00, 01, 02, 03, 04, 05, 06, 07, 08, 09, OA, OB...0Z, followed by 10-1Z, 20-2Z, etc.

Acconcia, G., 0D, 01

Allard, Lars, 07

Allen, Gregory D., 09

Atkinson, Dani E., OA

Axelsson, Maria, 07

Baker, lan M., OA

Bienfang, Joshua C., OC

Bock, Megan, OB

Buck, Benjamin R., 09

Caramazza, Piergiorgio, 03

Cavanaugh, John, OB

Chen, Yongping, OF

Cheng, Zhengxi, OF

Dhulla, Vinit, $0 Q$

Dissanayake, Nanditha, $0 Q$

Duerr, Erik K., 09

Eshkoli, A., $\mathrm{OH}$

Faccio, Daniele, 03

Ghioni, M., OD, 이

Gill, Sawyer, 08

Glazenborg, René, OM

Gulinatti, A., OD, OI

Hall, Donald N. B., OA

Harris, James Z., 08

Henriksson, Markus, 07

Higham, Catherine F., 03

Holmes, Rebecca M., 08

Jacobson, Shane M., OA

Jonsson, Per, 07

Jorgensen, Anders M., 08

Kernen, Emilie, OM

Korzh, B., ON

Krainak, Michael A., OB

Labanca, I., OD

Lansford, Joellen S., 08

Lee, Adam O., OQ

Lita, A. E., ON

LU, Wei, OB

Lyons, Ashley, 03

Martino, Anthony J., OB

Mclntosh, K. Alexander, 09

Migdall, Alan L., OC

Mirin, R.P., ON

Moynihan, Shawn T., 09

Mukherjee, Sapna S., $0 Q$

Murray-Smith, Roderick, 03

Musarra, Gabriella, 03

Myers, Charles, $0 Q$

Myers, Riley, 08
Nam, S. W., ON

Nemirovsky, A., $\mathrm{OH}$

Nemirovsky, Y., $\mathrm{OH}$

Orlov, Dmitry A., OM

Ortega, Raquel, OM

Palmer, David M., 08

Rech, I., OD, Ol

Restelli, Alessandro, $0 \mathrm{C}$

Ryu, Booshik, OQ

Shaw, M. D., ON

Shukla, Vishwa N., 09

Sjöqvist, Lars, 07

Tolt, Gustav, 07

Turpin, Alex, 03

Verma, V. B., ON

Wang, Jeffrey D., 09

Weaver, Charles T., 08

Wollman, E., ON

$\mathrm{XU}$, Heliang, OF

Yang, Guangning, OB

Zucherman, Aaron P., 08 
Proc. of SPIE Vol. 10978 1097801-6

Downloaded From: https://www.spiedigitallibrary.org/conference-proceedings-of-spie on 26 Apr 2023 Terms of Use: https://www.spiedigitallibrary.org/terms-of-use 


\title{
Conference Committee
}

\author{
Symposium Chairs
}

Jay Kumler, JENOPTIK Optical Systems, LLC (United States)

Ruth L. Moser, Air Force Research Laboratory (United States)

Symposium Co-chair

John M. Pellegrino, Electro-Optical Systems Laboratory, Georgia Institute of Technology (United States)

Conference Chair

Mark A. Itzler, Argo Al, LLC (United States)

Conference Co-chairs

Joshua C. Bienfang, National Institute of Standards and Technology (United States)

K. Alex McIntosh, MIT Lincoln Laboratory (United States)

Conference Program Committee

Gerald S. Buller, Heriot-Watt University (United Kingdom)

Joe C. Campbell, University of Virginia (United States)

William H. Farr, Facebook Inc. (United States)

Robert H. Hadfield, University of Glasgow (United Kingdom)

Majeed Hayat, The University of New Mexico (United States)

Michael A. Krainak, NASA Goddard Space Flight Center (United States)

Robert A. Lamb, Leonardo MW Ltd. (United Kingdom)

Alan L. Migdall, National Institute of Standards and Technology (United States)

Ivan Rech, Politecnico di Milano (Italy)

Michael Wahl, PicoQuant GmbH (Germany)

\section{Session Chairs}

1 SPD Applications I: TOF Imaging

Mark A. Itzler, Argo Al, LLC (United States)

2 SPD Applications II: LADAR Imaging

K. Alexander McIntosh, MIT Lincoln Laboratory (United States) 
3 SPD Applications III: Space Detection

Michael A. Krainak, NASA Goddard Space Flight Center (United States)

$4 \quad$ SPADs and Electronics

Joshua C. Bienfang, National Institute of Standards and Technology (United States)

5 SPADs I

Alan L. Migdall, National Institute of Standards and Technology (United States)

6 Novel SPDs

Joe C. Campbell, University of Virginia (United States)

7 SNSPDS

Gerald S. Buller, Heriot-Watt University (United Kingdom)

8 SPADs II

Ivan Rech, Politecnico di Milano (Italy) 